\title{
Entrepreneurship and regional development. A bibliometric analysis
}

\author{
Mihaela-Cornelia DAN \\ The Bucharest University of Economic Studies, Bucharest, Romania \\ mihaela.dan@fabiz.ase.ro \\ Simona Irina GOIA (AGOSTON) \\ The Bucharest University of Economic Studies, Bucharest, Romania \\ simona.goia@ase.ro
}

\begin{abstract}
Entrepreneurial initiatives and actions are considered main triggers of economic and social development as well as important factors in order to achieve more cohesion among various countries and regions within the European Union. The main goal of the present paper consists in analyzing the scientific literature on entrepreneurship and its influences on regional development. In the first section of the paper the concepts of entrepreneurship and regional development are broken down from the perspective of various researchers. Next the link between entrepreneurship and regional development is established and it is analyzed how the two terms are interconnected: entrepreneurship might have a positive contribution to the development of a region and in the same time some regions are more attractive for entrepreneurs than others. In the last section of the paper a bibliometric analysis is conducted, which aims at establishing the interest existing in the scientific literature for this research topic based on different criteria such as: number of publications, language of publication, journals where articles have been published, areas of knowledge in which authors have published research on entrepreneurship and regional development etc. The analysis was conducted based on scientific literature published between 2001 and 2017 and indexed in the Web of Science - Core Collection. It is highlighted that most of the publications on entrepreneurship and regional development are articles, published in English in the field of Business economics. Overall, the positive trend regarding the number of publications on this topic reveals a growing interest for this research area.
\end{abstract}

Keywords: entrepreneurship, development, regional development, bibliometric analysis, Web of Science

\section{Introduction}

The term Entrepreneur comes from the French verb entreprendenre, which means "to do something" or "to undertake something". First mentions and descriptions of entrepreneurship come from the $18^{\text {th }}$ century when many French and Italian economists defined entrepreneurship in connection with an economic activity with an uncertain profit/outcome.

Entrepreneurship developed into many forms and structures along with the industrial revolution, the events from the beginning of the $20^{\text {th }}$ century, the two World Wars, and later on in connection with the formation and enlargement of the European Union. The economic and financial crisis from 2008 brought again under discussion the role of new business in the economy, the opportunities for development triggered by entrepreneurial initiatives. In the European Union there is still a significant difference between countries and regions regarding the role of small and medium enterprises in the local economy, the awareness of entrepreneurship or benefits brought by local businesses for the population, production, markets etc.

Today, many potential entrepreneurs criticize the tough environment, the lack of entrepreneurial education, the difficult access to funds, loans and markets and 
moreover, the bureaucracy and administrative procedures, especially when using European money (EC, 2011). The New Member States are facing the same situation even more intensively, because they include the majority of the less developed regions with rural areas and low income population.

The scope of this paper is to analyze the scientific literature on entrepreneurship and its influences on regional development and to help researchers and practitioners develop responses to the current socio-spatial and economic crisis.

The paper starts by defining the concept of entrepreneurship, describe the main types of entrepreneurship, discuss the characteristics and skills of an entrepreneur. Next we explain the concept of regional development, and define the term of region and the understandings around the term development. Being a vague concept, it is difficult to illustrate in few words what development is. The majority of the researchers agrees that development must be defined based on qualitative and quantitative indicators.

The link between entrepreneurship and regional development is established by discussing about local conditions, which act as an attraction pole for entrepreneurs and organizations. The role of entrepreneurial culture is taken also into discussion.

In order to check the awareness and interest for the research subject of this paper, we conducted a bibliometric analysis on the scientific literature published between 2001 and 2017 and indexed in the Web of Science - Core Collection. We chose this database because it comprises articles from various research areas and therefore we can observe if entrepreneurship and regional development lie in the focus of economists, or also other researchers look at this subject with the same interest.

This paper is original because it contributes to the alternative research on the implications of entrepreneurship to regional development, by highlighting in the same time the trends existing in the scientific literature on this topic indexed in the Web of Science- Core Collection in the last 17 years.

The limits of this paper consists mainly in the restricted access to scientific databases and implicitly the incapacity to choose from a more diverse list of scientific articles.

\section{Brief literature review on entrepreneurship and regional development \\ The concept of entrepreneurship}

The attempts of defining entrepreneurship can be traced back to the time when researchers revealed some interesting statements summarized by Kao (1993) in one pioneering article about this concept. He puts forth the definition of Richard Cantillon, an Irish economist from 1730 who defines entrepreneurship as "self-employment with an uncertain return" or the definition of Nicholas Baudeau (a French economist) from 1760 who defines it as "innovative management" or later on the definition of Joseph Schumpeter focused on "the entrepreneur as an innovator, carrying out new combinations".

In the modern economy, many authors define entrepreneurship as a process of creating new added value by investing time and effort and assuming financial, social and psychic risks and uncertainties for a monetary and personal satisfaction (Shah, 2015; Schindehutte et. al., 2008). Others researches focus on the characteristics and functions of the entrepreneurial process. Drucker (1985) and Kuratko (2009) emphasize the importance of innovation, risk-taking and proactiveness for entrepreneurship and entrepreneurs. 
Some authors (Felicio et al., 2012; Beugelsdijk \& Noorderhaven, 2005; Smallbone \& Welter, 2001) focus on the traits of entrepreneurship and entrepreneurs. Fritsch (2016) proposes the following features as main characteristics of an entrepreneur:

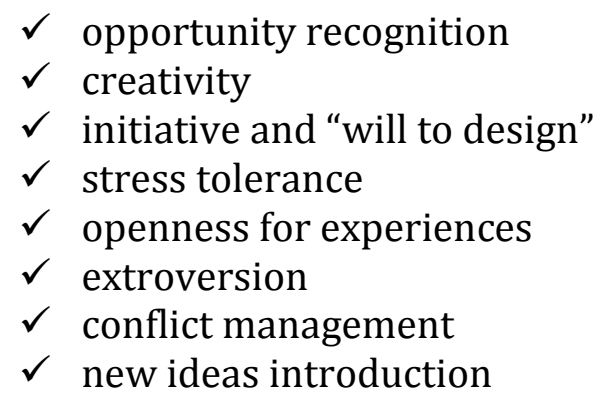

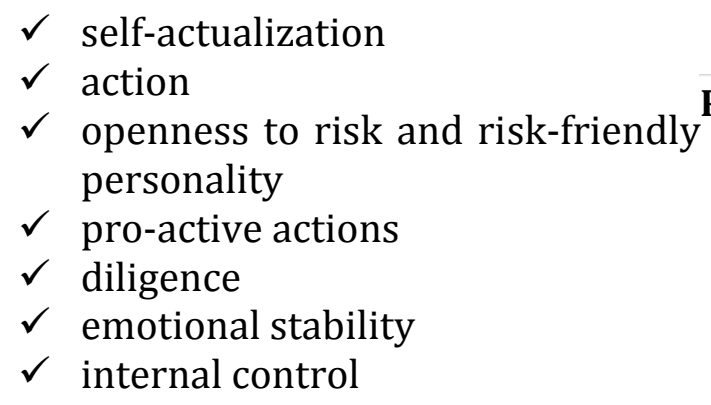

Certainly, these characteristics are rooted both in the educational background and personality of the entrepreneur. The openness for experience influences the determination and decision making ability, the extroversion is necessary for commercialization and active marketing measures, diligence helps handling and finishing different tasks. The emotional stability and conflict solving skills are necessary for a good business management.

The outcomes of entrepreneurship represent a research topic for many academics. Ault (2016), Audretsch et al. (2015), Soriano \& Dobon (2009), consider that entrepreneurship has in general a positive influence on economic development and outcomes as jobs, diversity in the industry, new product creation, innovative products and services have determined major changes for cities or regions. Wennberg \& Lindqvist (2010) go further and analyze the case of clusters, where several organizations, usually start-ups associate and use together their resources, such as human resources, information, knowledge, materials, location. In this way entrepreneurs can focus on their strengths and fill in the gaps with resources from their business partners.

\section{The concept of regional development}

Regional development is a complex concept because it requires to define first the region and second the meanings of development.

Regional development as a concept, but also as a discipline developed particularly after World War II and especially with the creation and enlargement of the European Union (EU). One of the main goals of the EU is to increase and maintain a higher economic level in all Member States and to decrease as much as possible the disparities between different regions.

The term of region has several understandings in the scientific literature and in the political discourse. A region may be a subnational territory (part of a state), a supranational territory (one group of neighbor countries, e.g. the Baltic States) or transnational (one territory that is included in several states, e.g. Tirol region with a surface in South Austria and Northern Italy) (Maier et al., 2006). In general, state policies concentrate on the subnational regions, they have the same institutions and the movements of goods, services and persons take place without restrictions.

A region may be defined in accordance with the interests and objectives of the public authorities, government or other economic and political actors, but sometimes might not correspond to the real needs of the local population. That is why Maier et al. (2006) recommend for a region to fulfill two conditions: 
$\checkmark$ the homogeneity criteria - the territories within a region should have similar key performance indicators (e.g. unemployment rate, income level, occupations in same economic sectors etc.)

$\checkmark$ the functionality criteria - the territories grouped within a region are interconnected and interdependent; for instance the local population is mobile between a bigger city and satellite smaller towns, commercial areas attract customers from a certain distance etc.

The concept of development raises many questions and meanings. It is a vague term and usually it is defined by performance indicators or the success of an organization, region or country. We may state that development refers to minimizing or removing the weaknesses, the disequilibrium or the social and economic shortages. The relation between economic growth and development is not clear enough. When a country or a region registers economic growth, we say it is developed, but, in the same time, it might have some deficits or losses. Seers (1989) ascertains that development starts with elements like food, work, social equity, and considers that a development policy has to combat hunger, unemployment and inequalities.

Based on this we consider that regional development is a broad term and seen as a complex effort to reduce disparities by supporting economic activities in regions. Starting with the 90's and due to various factors (Fall of Communism, EU enlargement process, openness of global market) there is a higher interest in the influences of entrepreneurship (especially the activity of local entrepreneurs) in the regions and on regional development. Politicians and economists accept today that economies that rely on the "big industry" cannot guarantee sufficient jobs for the population. Thus many countries started to invest more in the awareness toward entrepreneurship, benefits and chances for entrepreneurs as an alternative to a classical career. Countries started to invest in financial schemes and programs in order to support local initiative, to guarantee similar chances and an easy access to resources (human, natural, information, communication etc.) for a better development of the local businesses.

Under these conditions, some authors focus more on the link and interconnections between entrepreneurship and regional development. Is there enough evidence to state that entrepreneurship guarantees the regional development? Is it enough to offer support to local business in order to increase the wealth of a region?

\section{The link between entrepreneurship and regional development}

Before researching the influences of entrepreneurship on regional development it is necessary to present the general effects of entrepreneurship in an economy. Organizations enter into markets as start-ups or as enterprises established in other sectors. Through the market selection process organizations develop, increase their activity, or on the contrary they are forced to reorientation or decrease of economic processes. New enterprises bring new and more capacities on the market and they have a direct effect on the economic activity due to job creation and the market share they acquire. The indirect effect is exerted on the already established organization, through a more intensive competition or innovation pressure. Taking into account that the first objective of an enterprise on the market is not the profit, but the survival, it means that old organizations with similar capacities will remain on the market, while organizations with lower capacities will sell less and will be forced to market withdrawal.

Another important aspect of the new entrance on markets is the effect on the work force and its availability. The job creation might have sometimes a negative 
influence on markets: there are regions where there is a lack of human resources and this may further impact the payment levels and lead to higher costs for the existing organizations. Entrepreneurship development in a particular region or market is influenced by local conditions, starting with regulations and commercial laws, to tax system, insolvency rules, labor market regulations, market entry conditions, intellectual property rights etc.

One interesting approach has Alfred Marshall (1920) who, after observing the economic space around London in 1890 concluded that organizations were connected and beneficiaries of three factors: labor force pool, specialized suppliers and an easy access to knowledge and information. His observation was correct, these factors contributed indeed to the development of industrial zones and represent key elements of the economic development in the 19th century in Europe and in the U.S.A. In the modern economy we call these location conditions specific to a region or nation. They are very important because the enterprise/organization uses them in different ways and forms, such as transportation facilities, materials, labor force, urbanization level, energy, community infrastructure, capital, fields, buildings, environment and regional policy. These conditions are complex, tangible (e.g. costs, taxes) or intangible (e.g. trust frequency, quality and accessibility) (Hayter, 1997). It is well known that cities have more and diverse labour force markets, while in the territories with smaller population it is sometimes difficult to find the necessary personnel. In this situation the urban-rural differences determine the price of labour force, the tendency to entrepreneurship (one person with an average wage does not necessary think to become an entrepreneur) and access to skilled people (the entrepreneur covers the deficit of skills and competencies of specialized staff).

What drives entrepreneurship in a particular region? And how can the state or local authorities support entrepreneurship?

Possible factors that influence entrepreneurship are diverse and connected with the local conditions. Some of them are mentioned bellow:

$\checkmark$ research and development activities with innovative results that facilitate new market creation or a higher productivity and better competitive ability;

$\checkmark$ economic growth and structural change;

$\checkmark$ socio-demographic changes - especially in the regions with a lower birth rate and higher life expectancy there is a higher need for social services;

$\checkmark$ political changes - dissolution of market entry barriers, easier access to local resources;

$\checkmark$ climate change - people and organizations are forced to search for alternative energy and fuel sources;

$\checkmark$ easier access to capital (e.g. state or European funding schemes designated for entrepreneurs as an alternative to expensive bank loans).

The influences of entrepreneurship on regional development are very often researched on international level and in a comparative way. Since 1999 the Global Entrepreneurship Monitor (GEM) publishes yearly a report and the conclusions provide a direct connection between entrepreneurship and wealth and economic development in different regions. Depending on the local conditions and demand, there are regions where entrepreneurship is a solution to address certain necessities (usually regions with lower economic level) and regions where entrepreneurs seek exclusively for market opportunities. In the latest GEM report (2017) countries are grouped by three types of entrepreneurship: a. countries with a lower GDP as India, Iran or Russia are 
factor driven- where entrepreneurs have access to cheaper labour force or resources; $b$. countries with a medium development level like China, Thailand, Bulgaria or Brazil show an efficiency driven entrepreneurship and seek for solutions for a higher productivity and increase of competitiveness ability; c. the group of developed countries (Israel, Germany, Canada, U.S.A.) that are innovation-driven and entrepreneurs are socalled Born Globals- they search for solutions that can be instantly sold and applied worldwide.

The differences between regions regarding entrepreneurship and development are influenced by the local entrepreneurial culture. Regional conditions influence directly and indirectly entrepreneurship. One direct effect is the variable behaviour of the entrepreneur from different regions. And one indirect effect is the fact that some sectors or industries need entrepreneurs with special skills and because of location conditions they are concentrated is a particular region (e.g. the region of Bucharest or Cluj- Napoca as a hub for IT services in Romania). But this type of concentration is also a consequence of high education investments, of the fact that an important part of the local population has entrepreneurial activity or the region offers better conditions for entrepreneurs. We know that cultural factors change more slowly than formal rules. Entrepreneurs search for models which are seen as examples- some entrepreneurs say "If he can do this, I can do it too". The GEM Report (2017) reveals that the regional culture can influence the perception of entrepreneurship. Thus people can perceive entrepreneurship as a good career choice, give a high status to successful entrepreneurs and give a high media attention to successful stories. And nevertheless the local demand creates entrepreneurial conditions and stimulates in a positive way the evaluation and perspectives for business success.

\section{Bibliometric analysis of entrepreneurship and regional development literature}

After briefly presenting the concepts of entrepreneurship, regional development and the links between the aforementioned terms, we aim at establishing the interest existing in the scientific literature for this subject expressed by indicators such as number of publications, and organizational origins of authors.

The research methodology is specific for the research purpose and includes bibliometric analysis, synthesis of data and the dissemination of results.

The bibliometric analysis is based on statistical methods and determines - both from a qualitative and a quantitative perspective - the evolution and changes of a particular research topic (Marti et al., 2016). This study uses the Web of Science (WOS) online database, because it hosts scientific documents (articles, book chapters and proceedings papers) from various disciplines. In this way we can determine if the concepts of entrepreneurship and regional development are also in the focus of other researchers than economists. Also the Web of Science provides data on output, dissemination, citation and impact.

In general, a bibliometric analysis may include the following indicators:

$\checkmark$ Areas of research and knowledge in which authors published researches on a specific topic

$\checkmark$ Language of publication

$\checkmark$ Changes in the number of publications on the specific topic

$\checkmark$ Authors' country of origin

$\checkmark$ Journals in which authors have published

$\checkmark$ Authors who have published 
$\checkmark$ Citation analysis on the publication impact

$\checkmark$ H-index of the authors

$\checkmark$ Comparing the number of citations per article

$\checkmark$ Comparing the ranking of journals in the quartiles (Q1, Q2, Q3, Q4)

In order to build a more detailed image on the link between entrepreneurship and regional development, the nature of research, points of interests and other facts, we PICBE | 282 decided to start with the research areas analysis and in a next stage to identify the main journals that publish articles on these subjects. An analysis of the frequency distribution per year helps us analyze the trends and importance in the research areas of these topics.

The analysis of the research areas starts with a list of keywords that were searched in the WOS. The list is based on authors' previous experience and knowledge within this field. A simple search of entrepreneurship and regional development in the topic of the scientific documents (articles, book chapters and proceedings papers) published between 2001 and 2017 in the WOS shows 1147 results, out of which 738 are articles, 350 proceedings papers and the rest book chapters, book reviews, editorial materials, reviews, books and bibliographical items. Given the nature of the present research and the limits in full accessing the database, we decided to focus only on articles. It is worth to mention that scientific articles are the most cited item in the scientific process and the first option when building the literature review.

After refining the search, the WOS identifies the main research areas with publications on this subject which are presented in Table 1. Because some journals belong to several research areas, articles published here are counted for each area the journal belongs to. For instance, the journal European Planning Studies is indexed in three categories: Environmental Studies, Geography and Urban Studies.

Table 1. Areas of knowledge in which authors have published research on entrepreneurship and regional development

\begin{tabular}{|l|c|c|}
\hline Research areas & Records & $\begin{array}{l}\text { \%of } \\
\text { articles }\end{array}$ \\
\hline BUSINESS ECONOMICS & 504 & 68.293 \\
\hline PUBLIC ADMINISTRATION & 176 & 23.848 \\
\hline GEOGRAPHY & 153 & 20.732 \\
\hline ENVIRONMENTAL SCIENCES ECOLOGY & 145 & 19.648 \\
\hline URBAN STUDIES & 66 & 8.943 \\
\hline ENGINEERING & 38 & 5.149 \\
\hline SOCIAL SCIENCES OTHER TOPICS & 21 & 2.846 \\
\hline SCIENCE TECHNOLOGY OTHER TOPICS & 20 & 2.710 \\
\hline AREAS STUDIES & 17 & 2.304 \\
\hline OPERATIONS RESEARCH MANAGEMENT SCIENCE & 16 & 2.168 \\
\hline EDUCATION EDUCATIONAL RESEARCH & 15 & 2.033 \\
\hline SOCIOLOGY & 13 & 1.762 \\
\hline GOVERNMENT LAW & 11 & 1.491 \\
\hline
\end{tabular}

The rest of the articles are spread among other 14 different research areas and they do not influence the ranking from Table 1.

Besides the research areas, it is interesting to analyze the results based on the WOS categories, which are more accurate and show better to which themes authors relate entrepreneurship and regional development. The results are shown in Table 2. 
Table 2. Web of Science Categories that include articles on entrepreneurship and regional development

\begin{tabular}{|l|c|c|}
\hline Web of Science Categories & Records & \% of 738 \\
\hline ECONOMICS & 249 & 33.740 \\
\hline BUSINESS & 224 & 30.352 \\
\hline MANAGEMENT & 199 & 29.965 \\
\hline GEOGRAPHY & 153 & 20.732 \\
\hline PLANNING DEVELOPMENT & 150 & 20.325 \\
\hline ENVIRONMENTAL STUDIES & 139 & 18.835 \\
\hline URBAN STUDIES & 66 & 8.943 \\
\hline PUBLIC ADMINISTRATION & 30 & 4.065 \\
\hline ENGINEERING INDUSTRIAL & 30 & 4.065 \\
\hline AREA STUDIES & 17 & 2.304 \\
\hline OPERATIONS RESEARCH MANAGEMENT SCIENCE & 16 & 2.168 \\
\hline EDUCATION EDUCATIONAL RESEARCH & 15 & 2.033 \\
\hline ENVIRONMENTAL SCIENCES & 14 & 1.897 \\
\hline GREEN SUSTAINABLE SCIENCE TECHNOLOGY & 13 & 1.762 \\
\hline SOCIOLOGY & 13 & 1.762 \\
\hline SOCIAL SCIENCES INTERDISCIPLINARY & 10 & 1.355 \\
\hline HISTORY & 9 & 1.220 \\
\hline POLITICAL SCIENCE & 8 & 1.084 \\
\hline HOSPITALITY LEISURE SPORT TOURISM & 7 & 0.949 \\
\hline MULTIDISCIPLINARY STUDIES & 7 & 0.949 \\
\hline BUSINESS FINANCE & 6 & 0.813 \\
\hline ENGINEERING MULTIDISCIPLINARY & 6 & 0.813 \\
\hline HISTORY OF SOCIALE SCIENCES & 5 & 0.678 \\
\hline GEOGRAPHY PHYSICAL & 4 & 0.542 \\
\hline
\end{tabular}

Note: 11 Web of Science Categories $\{0\}\{1\}$ value(s) outside display options

Source: Authors' own research.

The next step in the bibliometric analysis is to rank the source titles or the journals that published in the researched time period the largest number of articles on entrepreneurship and regional development (Table 3). Having information about the journals and their research focus is helpful when deciding which journals to include and to read for a literature review. In this case, as expected, the most active journal in this area is Entrepreneurship and Regional Development with 49 publications in the last 17 years, followed by Small Business Economics (with 47 publications), a journal that covers many aspects of Entrepreneurship and Regional Studies (with 45 publications), a journal outside the research area of Business \& Economics but situated at the fine line between Economics and Economic Geography. Because of the research term "Regional development" it is expected that many journals from categories like Urban development, Economic development or Public Administration cover extensively this subject (e.g. European Planning Studies with 24 articles, Economic Development Quarterly with 16 articles, Annals of Regional Science with 11 articles).

Table 3. Journals that have published research on entrepreneurship and regional development

\begin{tabular}{|l|c|c|}
\hline Source Titles & Records & \% of 738 \\
\hline ENTREPRENEURSHIP AND REGIONAL DEVELOPMENT & 49 & 6.640 \\
\hline SMALL BUSINESS ECONOMICS & 47 & 6.369 \\
\hline REGIONAL STUDIES & 45 & 6.098 \\
\hline EUROPEAN PLANNING STUDIES & 25 & 3.388 \\
\hline ECONOMIC DEVELOPMENT QUARTERLY & 17 & 2.304 \\
\hline
\end{tabular}




\begin{tabular}{|l|c|c|}
\hline JOURNAL OF TECHNOLOGY TRANSFER & 17 & 2.304 \\
\hline ENVIRONMENT AND PLANNING C: GOVERNMENT AND POLICY & 16 & 2.168 \\
\hline ANNALS OF REGIONAL SCIENCE & 11 & 1.491 \\
\hline GROWTH AND CHANGE & 10 & 1.355 \\
\hline RESEARCH POLICY & 10 & 1.355 \\
\hline TECHNOVATION & 10 & 1.355 \\
\hline ECONOMIC AND SOCIAL CHANGES FACTS TRENDS FORECAST & 7 & 0.949 \\
\hline EKONOMIKA REGION ECONOMY OF REGION & 7 & 0.949 \\
\hline INTERNATIONAL ENTREPRENEURSHIP AND MANAGEMENT JOURNAL & 7 & 0.949 \\
\hline JOURNAL OF EVOLUTIONARY ECONOMICS & 7 & 0.949 \\
\hline PAPERS IN REGIONAL SCIENCE & 7 & 0.949 \\
\hline SUSTAINABILITY & 7 & 0.949 \\
\hline ECONOMIC GEOGRAPHY & 6 & 0.813 \\
\hline JOURNAL OF BUSINESS VENTURING & 6 & 0.813 \\
\hline JOURNAL OF ECONOMIC GEOGRAPHY & 6 & 0.813 \\
\hline JOURNAL OF SMALL BUSINESS AND ENTERPRISE DEVELOPMENT & 6 & 0.813 \\
\hline TECHNOLOGICAL FORECASTING AND SOCIAL CHANGE & 6 & 0.813 \\
\hline ENVIRONMENT AND PLANNING A: ECONOMY AND SPACE & 5 & 0.678 \\
\hline INNOVATION TECHNOOGY AND KNOWLEDGE MANAGEMENT & 5 & 0.678 \\
\hline INTERNATIONAL JOURNAL OF ENTREPRENEURIAL BEHAVIOUR & 5 & 0.678 \\
\hline RESEARCH & & \\
\hline AMFITEATRU ECONOMIC & 4 & 0.542 \\
\hline CAMBRIDGE JOURNAL OF REGIONS ECONOMY AND SOCIETY & 4 & 0.542 \\
\hline CONTEMPORARY ISSUES IN ENTREPRENEURSHIP RESEARCH & 4 & 0.542 \\
\hline E M EKONOMIE A MANAGEMENT & 4 & 0.542 \\
\hline EUROPEAN URBAN AND REGIONAL STUDIES & 4 & 0.542 \\
\hline JOURNAL OF RURAL STUDIES & 4 & 0.542 \\
\hline SCIENCE AND PUBLIC POLICY & 4 & 0.542 \\
\hline
\end{tabular}

Note: 48 Source Titles value(s) outside display options

Source: Authors' own research.

As expected, the majority of the scientific work is published in English (691publications), only 19 in Spanish, 17 in Russian, three in Czech and two in Croatian. The language does not give information about authors' origin but reinforces again the role of English as lingua franca (see Table 4).

Table 4. Languages used in research on entrepreneurship and regional development

\begin{tabular}{|l|c|c|}
\hline \multicolumn{1}{|c|}{ Language } & Records & \% of 738 \\
\hline ENGLISH & 691 & 93.631 \\
\hline SPANISH & 19 & 2.575 \\
\hline RUSSIAN & 17 & 2.304 \\
\hline CZECH & 3 & 0.407 \\
\hline CROATIAN & 2 & 0.271 \\
\hline
\end{tabular}

Source: Authors' own research.

The number of articles on entrepreneurship and regional development published between 2001 and 2017 shows an increasing interest in this subject (see Figure 1). As mentioned before in this paper, the fact that at economic and political level there is a high involvement in the support offered to local entrepreneurs, opens for academics new research opportunities. 


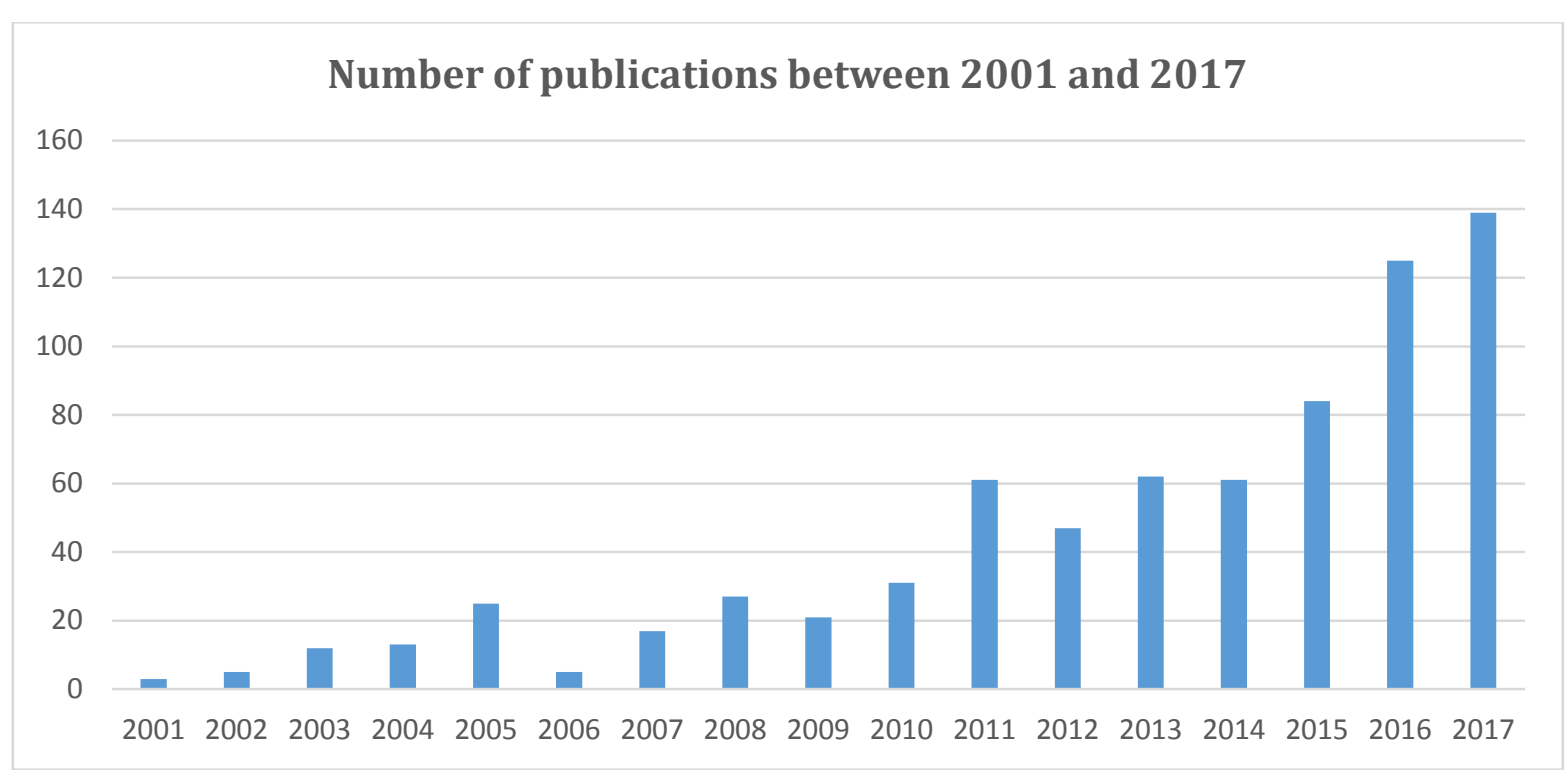

PICBE | 285

Figure 1. Number of publications between 2001 and 2017

Source: Authors' own research.

The analysis of the organizational origins of authors shows the main centers where entrepreneurship and regional development are in the research focus. In top 3 we find, Friedrich Schiller University of Jena (with 23 publications), Max Planck Society (with 17 articles) and the University of London (with 17 articles). Top 15 is presented in Table 5.

Table 5. Organizations with publications on entrepreneurship and regional development between 2001 and 2017

\begin{tabular}{|l|c|c|}
\hline \multicolumn{1}{|c|}{ Organization } & Records & \% of 738 \\
\hline FRIEDRICH SCHILLER UNIVERSITY OF JENA & 23 & 3.117 \\
\hline MAX PLANCK SOCIETY & 17 & 2.304 \\
\hline UNIVERSITY OF LONDON & 17 & 2.304 \\
\hline UNIVERSITY OF UTRECHT & 15 & 2.033 \\
\hline CARDIFF UNIVERSITY & 14 & 1.897 \\
\hline LUND UNIVERSITY & 14 & 1.897 \\
\hline AUTONOMOUS UNIVERSITY OF BARCELONA & 13 & 1.762 \\
\hline INDIANA UNIVERSITY BLOOMINGTON & 13 & 1.762 \\
\hline INDIANA UNIVERSITY SYSTEM & 13 & 1.762 \\
\hline ERASMUS UNIVERSITY ROTTERDAM & 12 & 1.626 \\
\hline GEORGE MASON UNIVERSITY & 12 & 1.626 \\
\hline UNIVERSITY OF NORTH CAROLINA & 12 & 1.626 \\
\hline JONKOPING UNIVERSITY & 11 & 1.491 \\
\hline LINKOPING UNIVERSITY & 10 & 1.355 \\
\hline
\end{tabular}

Note: 203 Organizations-Enhanced value(s) outside display options

Source: Authors' own research.

\section{Conclusion}

The present research paper focuses on the linkages between entrepreneurship and regional development. In order to achieve the research objective we conducted a short literature review and a bibliometric analysis of publications indexed in WOS between 2001 and 2017.

Benneworth (2004) states that there is high need for research on more factors that influence entrepreneurship in the peripheral regions, while ten years later Brekke 
(2015) questions the benefits of the systematic building of regional mechanisms considering the low number of start-ups in these regions. In his opinion the economic growth of a region depends on the industrial structure and diversity of industry. Johansson (2009) focuses on the importance of networks and emphasizes that entrepreneurship is not always innovation-driven and is more "an outflow of ordinary life". Kasseeah (2016) concludes that irrespective of the economic development level, any country or region will benefit from encouraging entrepreneurship. However he could not establish exactly if economic development is a determinant for new organizations' birth or if entrepreneurship on large scale leads to economic and regional development.

Through the bibliometric analysis we found out that entrepreneurship and regional development are important research topics: 1147 publications were published between 2001 and 2017. The number is very high compared to the total number of publications since the first indexation in WOS in 1975, namely 1189 publications.

As expected, this subject is more debated in Western European countries and in the USA due to the longer history and interest for entrepreneurs and economic development. There are dedicated journals, such as Entrepreneurship and Regional development and also other important Business \& Economics journals publish articles on this topic on a regular basis.

\section{References}

Audretsch, D.A., Belitski, M. \& Desai, S. (2015). Entrepreneurship and economic development in cities. Annals of Regional Science, 55 (1), 33-60.

Ault, J. (2016). An institutional perspective on the social outcome of entrepreneurship: Commercial microfinance and inclusive markets. Journal of International Business Studies, 47 (8), 951-967.

Benneworth, P. (2004). In what sense "regional development"?: entrepreneurship, underdevelopment and strong tradition in the periphery. Entrepreneurship \& Regional Development, 16 (6), 439-458.

Beugelsdijk, S. \& Noorderhaven, N. (2005). Personality Characteristics of Self-Employed. An Empirical Study. Small Business Economics, 24 (2), 159-167.

Brekke, T. (2015). Entrepreneurship and path dependency in regional development. Entrepreneurship \& Regional Development, 27 (3-4), 202-218.

Drucker, P. (1985). Innovation and Entrepreneurship, Practice and Principles. Harper Business.

European Commission (2011). Business Dynamics: Start-ups, Business, Transfers and Bankruptcy.

Felicio, J.A., Caldeirinha, V.R. \& Rodrigues, R. (2012). Global mindset and the internationalization of small firms: The importance of the characteristics of entrepreneurs. International Entrepreneurship Management Journal, 8 (4), 467485.

Fritsch, M. (2016). Entrepreneurship, Theorie, Empirik, Politik. Springer Gabler.

Global Entrepreneurship Research Association (2017). Global Entrepreneurship Monitor,

available at: http://www.gemconsortium.org/report .

Hayter, R. (1997). The Dynamics of Industrial Location: The Factory, the Firm and the Production System. Wiley.

Johansson, A.W. (2009). Regional Development by Means of Broadened Entrepreneurship. European Planning Studies, 17(8), 1205-1222. 
Kao, R.W.Y. (1993). Defining Entrepreneurship: Past, Present and ?, Creativity and Innovation Management, 2 (1), 69-70.

Kasseeah, H. (2016). Investigating the impact of entrepreneurship on economic development: a regional analysis. Journal of Small Business and Enterprise Development, 23 (3), 896-916.

Kuratko, D.F. (2009). The economy's one enduring force: Entrepreneurship. Business Horizons, 52(5), 405-407.

Maier, G., Tödtling, F. \& Trippl, M. (2006). Regional- und Stadtökonomik. Wiesbaden: Springer Verlag.

Marshall, A. (1920). Principles of Economics. $8^{\text {th }}$ Edition, London: MacMillan and Co.

Marti, A.R., Ribeiro-Soriano, D. \& Palacios-Marques, D. (2016). A bibliometric analysis of social entrepreneurship. Journal of Business Research, 69 (5), 1651-1655.

Schindehutte, M., Morris, M.H. \& Kocak, A. (2008). Understanding market-driving behavior: the role of entrepreneurship. Journal of Small Business Management, 46 (1), 4-26.

Shah, E. (2015). Innovation, Entrepreneurship, and the Economy in the US, China and India, Elsevier.

Seers, D. (1989). The meaning of development, with a postscript in Development Studies Revisited. Twenty-Five Years of Journal of Development Studies, London: Routledge, Taylor \&Francis Group.

Smallbone, D., Welter, F. (2001). The Distinctiveness of Entrepreneurship in Transition Economies, Small Business Economics, 16 (4), 249-262.

Soriano, D.R. \& Dobon, S.R. (2009). Linking globalization of entrepreneurship in small Organizations. Small Business Economics, 32 (3), 233-239.

Wennberg, K. \& Lindqvist, G. (2010). The effect of clusters on the survival and performance of new firms. Small Business Economics, 34 (3), 221-241. 